\title{
ARTES PLÁSTICAS EM FEIRA DE ARTESANATO: VENDA, CRIAÇÃO E OS OLHOS PARA VER A ARTE*
}

Este artigo trata de aspecto nem sempre enfocado da arte - a venda -, refletindo sobre as formas por meio das quais ela se liga a procedimentos criativos e a diversos atributos que costumam compor a identidade de artista, como o caráter original, individualizado e comercialmente desinteressado de sua produção. Analisando situação na qual artistas plásticos trabalham em feira de artesanato de Fortaleza, Estado do Ceará, Brasil, as aproximações e os distanciamentos das categorias artista/arte, de um lado, das categorias artesão/artesanato, de outro, contribuem para a reflexão sobre o significado variável de procedimentos vinculados à venda de seus produtos, as condições nas quais se realiza, e o quanto concorre para a diferenciação dos e entre artistas plásticos. O fato de na operação de venda artistas plásticos aquilatarem o valor artístico de seus trabalhos possibilita verificarmos como avaliam a própria capacidade de os indivíduos que frequentam o espaço da venda reconhecerem a qualidade artística desses trabalhos.

\section{VERDADEIROS ARTESÃOS E VERDADEIROS ARTISTAS}

A Feira de Artesanato da Praia de Iracema foi criada em 2009, em boa medida como resultado de um processo de ordenamento, feito pela Prefeitura de Fortaleza, capital do Estado do Ceará, do importante comércio voltado para o turismo na Avenida Beira Mar, ${ }^{\mathrm{I}}$ espaço frequentado também para lazer e compras 
pelos moradores dos bairros valorizados da região litorânea da cidade. A partir de pressão de moradores, frequentadores e lojistas dessa área da orla, e de feirantes permissionários da Feira de Artesanato da Beira Mar - importante centro de venda de produtos especialmente para turismo que funciona há décadas -, numeroso contingente de comerciantes ou feirantes ilegais, ou irregulares, ou vendedores ambulantes, foram impedidos de continuar atuando na área sem o aval da Prefeitura, e amplo recadastramento foi efetuado. Alimentos, refrigerantes, brinquedos "made in China", e muitos outros produtos, dentre eles pinturas em tela e artesanato, eram vendidos no calçadão da avenida, fora da área de cerca de $200 \mathrm{~m}^{2}$ ocupada pelos boxes de permissionários da feira. Entre os trabalhadores impedidos de atuar na região estavam artesãos, alguns deles ambulantes, outros atuando em pontos fixos às vezes ocupados há anos. E, dentre esses artesãos, havia os que participavam de pequenas feiras nas imediações da Feira de Artesanato da Beira Mar e por toda a orla, organizadas por associações de artesãos e pelo Sindicato dos Artesãos Autônomos do Estado do Ceará - Siara. ${ }^{2}$

Atingindo outros trabalhadores além dos artesãos, no decorrer do confuso e dramático processo que reordenou o comércio voltado para o turismo na avenida Beira Mar $^{3}$ e que concorreu para a criação da Feira de Artesanato da Praia de Iracema, os artesãos impedidos de continuar atuando na orla foram mencionados das mais diferentes maneiras pela imprensa e pelos diversos atores sociais e agências envolvidos. Com frequência foram englobados pela categoria comerciantes irregulares ou ilegais, vendedores ambulantes, não permissionários, quando o eventual caráter ilícito de sua atividade era sublinhado. Algumas vezes foram tratados como artesãos, em oposição aos vendedores de mercadorias confeccionadas por terceiros, meros comerciantes, em alguns contextos especialmente aos que vendiam produtos industrializados. Finalmente, depois de processo que contou com intensas negociações do Siara, das associações de artesãos envolvidas e da Prefeitura, tratamento e destino diferente aos dos demais trabalhadores foram dados aos verdadeiros artesãos, que produziam e vendiam suas mercadorias, artesanato, na avenida Beira Mar e eram sócios do Sindicato. Para eles estava sendo organizada aquela feira, a Feira de Artesanato da Praia de Iracema, em terreno de aterro na Praia de Iracema, onde há movimentação de turistas e de moradores da cidade, mas em escala muitíssimo menor que a da região da Beira Mar. E os artesãos não sindicalizados que atuavam na área da Beira Mar, e tantos outros que se interessaram, passaram, então, a ter que providenciar sua sindicalização para que também pudessem participar dessa nova feira.

O processo de sindicalização dos artesãos envolve um conjunto de procedimentos voltados para o disciplinamento da atividade. O Centro de Artesanato do Ceará, o Ceart, vinculado à Secretaria do Trabalho e Desenvolvimento Social do Estado do Ceará, fornece uma carteira de artesão, mediante pagamen- 
to de taxa única e teste que consiste na elaboração, diante de avaliadores, de produtos de uma ou duas tipologias ${ }^{4}$ - por exemplo, xilogravura, cerâmica, madeira, vestuário, couro. Trata-se da comprovação de que o candidato é capaz de confeccionar as peças, isto é, de habilidade e da autoria. Uma vez dispondo dessa carteira, o artesão estará isento de determinados impostos e liberado para a venda de seus produtos. E poderá sindicalizar-se, pagando mensalidade ao Siara, ou participar de alguma das tantas associações de artesãos de Fortaleza, tendo com isso, então, acesso a diversas feiras e eventos que organizam em espaços estabelecidos junto à Prefeitura para a venda de seus produtos, e obtendo financiamentos bancários, dentre outras vantagens. Poderá também contar mais facilmente com cursos e assessorias fornecidas pelo Serviço Brasileiro de Apoio às Micro e Pequenas Empresas - o Sebrae - e outras entidades de apoio, que também organizam eventos, por exemplo em hotéis, onde os artesãos podem vender seus produtos. ${ }^{5}$

Além das contribuições para sindicato e associações, os artesãos costumam ter, nas feiras permanentes, como a da Praia de Iracema, que pagar taxa semanal para os fornecedores das cadeiras e das mesas de plástico onde os seus produtos são expostos para a venda. Na Feira da Praia de Iracema, a disposição dessas mesas e cadeiras formam alas, cada uma juntando artesãos e artesanato de uma determinada tipologia. Iniciada com cerca de 300 artesãos, participam hoje da feira em torno de I40, organizados em doze alas: "calçados", "bonecas", "bolsas", "crochê", "lembranças", "cama, mesa, banho e tapeçaria", "renda", "roupas bordadas e pintadas", "bijuteria", "alimentos típicos", "talhas" e "artes plásticas". ${ }^{6}$

Nessa contabilidade incluem, portanto, os artistas plásticos, que em 2009, no início de funcionamento da feira, eram em torno de 50,7 com suas telas apoiadas em toda a extensa amurada que separa a área aterrada do mar. Hoje não chegam a ıo "os que insistiram", essa diminuição sendo atribuída, pelos artesãos e organizadores da feira, ao vento forte que vinha com água e areia da praia, sujando e derrubando telas, incomodando os próprios artistas e afastando potenciais compradores. Segundo artistas plásticos que lá permanecem, houve primeiro uma "debandada dos atravessadores", "que não eram os verdadeiros artistas, apenas vendiam as telas", e que tinham afluído com eles à recém-criada Feira da Praia de Iracema quando foram proibidos - artistas plásticos e atravessadores -, naquela operação de disciplinamento do comércio na orla da cidade, de permanecer vendendo telas ao lado da movimentada Feira da Beira Mar. Mas houve também a desistência de "verdadeiros artistas plásticos" que "quebraram" com a transferência para a não tão movimentada Feira da Praia de Iracema. Alguns desses artistas não vieram da Beira Mar, mas, como diversos artesãos, resolveram também juntar-se à nova feira, providenciando carteira de artesão junto ao Ceart, como todos os que hoje, artesãos ou artistas plásticos, vendem sua produção na Feira da Praia de Iracema. 
É relativamente comum a presença de artistas plásticos em feiras de artesanato, onde ocupam em geral áreas específicas e bem situadas, que concorrem para distingui-los dos artesãos, sempre em maior número. Na Feira da Praia de Iracema, não utilizam aquelas mesas e cadeiras, mas expõem ao público boa parte de suas telas e quadros no chão, ou presos em armações e grades de ferro ou ainda apoiadas naquela amurada. Transeuntes talvez não se deem conta da classificação artistas plásticos, usada por artesãos e coordenadores da feira, ${ }^{8}$ e que artesãos muitas vezes justificam por conta do suporte diferenciado que os artistas plásticos utilizam: "são artistas plásticos porque pintam quadros, telas". Na verdade, essas distinções costumam ser um tanto variáveis, e os próprios artistas plásticos acionam numerosos elementos para estabelecê-las, para muito além do suporte que usam na confecção de seus trabalhos.

Se para os artesãos da Feira da Praia de Iracema parece estar naturalizada a presença de artistas plásticos ali, os artistas sempre tomam o local como provisório. ${ }^{9}$ Boa parte enfatiza não ter havido uma política adequada da Prefeitura em relação aos verdadeiros artistas plásticos naquelas ações de ordenamento do comércio na orla, acabando por tratá-los como aos atravessadores, impedindo-os, todos, de trabalhar na Beira Mar, ou não se preocupando em transferi-los para local tão movimentado quanto: "Estamos esse tempo todo esperando um lugar melhor. Mas vamos resistindo até quando der. Ajudamos a formar esse local. Era abandonado, não tinha nada".

Mas há os que associam o caráter provisório de sua permanência na feira à profunda inadequação que pensam haver em um artista plástico trabalhar "como se fosse artesão": "O que eu faço não tem nada a ver com artesanato. Quer dizer, não tinha. Eu sou uma artista. Aqui eu estou me prostituindo. Sabe aquele trabalho amarelo ali? Já fiz uns trinta iguais".

\section{REPETIÇÃO E CRIAÇÃO}

Diferente da maioria dos artistas plásticos que estão na feira, essa artista a considera necessária pouso depois de uma série de problemas que teve em sua carreira, após anos de permanência em país europeu onde era vista como artista plástica, expunha em galerias e tinha seu trabalho tratado por crítica especializada: "Lá eu criava. Desenvolvia um trabalho, realmente. Aqui eu faço a mesma coisa se alguém pedir. Isso, para mim, é artesanato". Contrapor arte a artesanato a partir da repetitividade, do não reconhecimento nele das operações criativas da arte, parece ser operação muito frequente entre artistas plásticos. Alguns que vendem seus trabalhos há muitos anos em local da orla de Fortaleza conhecido como Alambrado, e que não foram afetados por aquelas operações de ordenamento da Beira Mar pela Prefeitura, ponderam sobre o quanto é impróprio artistas plásticos venderem seus trabalhos em feira de 
artesanato: "Aqui no Alambrado só tem artista plástico, pinturas e esculturas. Arte é arte, artesanato é artesanato. [...] Todo artista plástico é artesão. Mas poucos artesãos são artistas plásticos. A diferença é que o artesão está sempre fazendo a mesma coisa, e o artista sempre está criando".

A noção de repetição de procedimentos de produção e de padrões estéticos é amplamente acionada em contraste com a ideia de criação, e não raro aparece associada ao artesanato por diferentes artistas, perpassando já a formação escolar de numerosos deles. ${ }^{\circ}$ Ela costuma ser atribuída à vinculação que a pintura e a escultura tiveram historicamente com as chamadas "arts mécaniques", em oposição às "arts libéraux" (Nathalie-Heinich, I996), havendo uma correlação importante, como aponta Norbert Elias (I995), entre, de um lado, a "arte de artesão" e a "arte de artista", livre e insubordinada, e, de outro, os respectivos lugares na estrutura social que artesãos e artistas ocuparam ao longo do tempo. Parte razoável da literatura sociológica acerca da arte também utiliza classificações apoiadas em distinções dessa ordem, ainda quando, como faz Howard Becker (I982), são assinalados trânsitos e continuidades de fato entre arte e artesanato. ${ }^{11} \mathrm{O}$ atributo da criatividade é sempre remetido ao artista, ao artesão sendo referidas principalmente as funções utilitárias de sua produção e o virtuosismo de sua prática.

Para a maioria dos artistas plásticos que trabalha na Feira da Praia de Iracema ao lado de artesãos, a oposição arte/artista $x$ artesanato/artesão parece não operar de maneira tão enfática, afora quando indagamos a respeito: " $\mathrm{Na}$ verdade, sou trabalhador da arte, um operário da arte. Mas também sou artista plástico. Sou artesão e artista. Sou os dois". Marcando sua origem social - que os remeteria a trabalhos braçais não fosse, segundo afirmaram, o dom que teriam insistido em assumir e desenvolver -, e a necessidade de produção para a sobrevivência como condição que em alguma medida os aproximaria dos artesãos, seus depoimentos sublinham o caráter não necessariamente repetitivo de seu trabalho. Reconhecem, por exemplo, copiar em determinadas peças estilo de hoje famoso pintor nordestino que vive em Miami, identificadas facilmente e procuradas por compradores e para cuja confecção mobilizam, inclusive, a ajuda de seus familiares, o que não costuma ocorrer com seu próprio trabalho. Alguns não assinam essas peças, diferenciando-as daquelas que criaram. Mas o que é visto como repetição em suas telas pelos artistas plásticos do Alambrado e mesmo por alguns da própria Feira da Praia de Iracema, consiste, para esses artistas plásticos, em derivações de criações de sua própria autoria: "Esses eu sempre faço desse jeito. E é claro que eu assino. É meu, eu que criei. Eu que trouxe esse estilo. Ninguém tinha feito antes".

A percepção da produção dos artistas da Praia de Iracema como reprodução de procedimentos, de peças e padrões - o que também a literatura sociológica costuma reconhecer no artesanato - aparece para boa parte desses artistas como acusação descabida, ou engano derivado de incompetência para 
se perceber variações no seu trabalho pictórico. Um desses artistas demonstra, analisando diversas das suas telas "estilo postal", que retrata paisagens litorâneas com coqueiros e jangadas à luz da lua, "muito procurado por turistas e por cearenses mesmo", variantes que considera fundamentais: "Eu mudo o número de jangadas, a cor, formas. Eu tento uma coisa, tento outra. Veja a diferença. Nunca é a mesma coisa. Se olhar bem, até o tamanho é diferente. Não é cópia. Quem diz que é cópia é porque não sabe ver a diferença, não sabe nada de arte". E orienta: "Toda vez que você achar que um artista está se repetindo, veja se [...] ele não está repetindo, mas para mudar". ${ }^{\text {I2 }}$

Dentre os que sublinham o caráter repetitivo da produção desses artistas estão alguns vendedores de telas, os chamados por eles de "atravessadores" que atuam em muitos pontos da cidade, como os regularizados em boxes na Feira da Beira Mar. Esses comerciantes por vezes equiparam a produção das telas que recebem - inclusive dos artistas plásticos da Feira da Praia de Iracema - a qualquer trabalho mecânico e desqualificado: "O cara pinta dez telas com jangada, tudo igual. Vendeu, girou: traz mais dez. Podia estar vendendo milho, mas aprendeu a pintar tela. Não é arte, é no máximo, no máximo, arte comercial”. A generalização dessa prática de repetição, segundo alguns desses vendedores, atingiria mesmo artistas do Alambrado, ciosos por diferenciar sua produção do artesanato e do trabalho de artistas plásticos como os da Feira da Praia de Iracema: "Fala, fala dos outros, mas repara: se ele vende um quadro, vai lá no dia seguinte e vai ver que aparece pendurado outro igualzinho, a mesma coisa".

Para um dos artistas plásticos da Feira da Praia de Iracema, esse tipo de avaliação da sua produção feita pelo "pessoal do Alambrado", ${ }^{13}$ além de não fazer justiça à qualidade das telas, corresponde ao desconhecimento da impossibilidade de repetição na arte: "Nem que se queira, se copia um trabalho. Vai ser sempre diferente”. Artesãos também, salientando seus próprios limites técnicos, indicam a incapacidade de qualquer artista ou artesão repetir um trabalho: "Quem disser que faz dois trabalhos idênticos, está mentindo. Mesmo quem copia do outro não faz igual. Isso é impossível”. Para uma artesã, tudo é uma questão de interesse de quem observa e avalia os trabalhos: "Se eu venho aqui e quero dizer que artesão faz tudo igual, essas minhas bolsinhas, por exemplo, todas iguais, eu vou ver isso. Mas eu posso ver também as diferenças, só as diferenças, se eu quiser. Cada uma é uma".

Ao verem sugerido que o trabalho artesanal estaria baseado na cópia, ou que a prática de artistas plásticos que trabalham na Praia de Iracema possuiria um caráter artesanal, e por isso reprodutor, artesãos e artistas da Feira da Praia de Iracema reagem especialmente afirmando essa impossibilidade de repetição. Contudo, noutros contextos, ambos, artistas plásticos e artesãos, enfatizam o quão inventivo é seu trabalho. Demoram-se em detalhes ao indicar suas criações, modelos, texturas, estabelecendo a própria natureza - sobretudo dificul- 
dades na manipulação - do material ou da encomenda como deflagradoras de inovações no que fazem. Elizabeth Hallam e Tim Ingold (2007) descrevem muitas das dificuldades no reconhecimento, também na arte, de processos de transformação que acompanham procedimentos de improviso, não ditados por intencionalidades explícitas prévias. ${ }^{\mathrm{I} 4}$ Atentam para o quanto se distanciam do que tomamos hoje por criatividade, normalmente ocorrência projetada e de aparência súbita, contrastiva em relação a práticas e padrões precedentes, e altamente individualizada. Mas, para artistas e artesãos, esses processos criativos adaptados, por assim dizer, àquelas exigências que indicam referências a tipologias amplamente reconhecidas, ${ }^{15}$ adequados, portanto, a atividades que resultam na venda de seus produtos de modo a garantir sua sobrevivência, não dariam conta de todas as suas experiências artísticas e criativas.

Ao contrário do que costumamos considerar, o ímpeto criativo perpassa a experiência de trabalho desses artesãos e de artistas cuja produção é percebida tão comumente como repetitiva. São numerosos os relatos de situações, deflagradas pelas mais diferentes razões, que os levam à utilização de procedimentos, à produção de peças e à imaginação de resultados os mais inusitados Uma artesã, por exemplo, contou que acorda às vezes mais cedo para poder confeccionar uma peça que, "do nada", dispôs-se a inventar: "Eu fico como que agarrada nela". Fugindo consideravelmente do tipo de artesanato que costuma produzir, ata-se, contudo, à sua feitura, horas e horas na oficina que tem em casa, a ponto de o marido perguntar se não vai "voltar a trabalhar": "E tenho mesmo que largar tudo e voltar para o meu trabalho, senão, não tenho o que trazer". Indagada se colocaria à venda a tal peça na feira, nega, contundente, a possibilidade: "não tem nada a ver uma coisa com a outra".

Tais experiências não compõem o discurso primeiro sobre processos de criação e de invenção que artesãos e artistas plásticos da Feira da Praia de Iracema apresentam, nem essas peças especialíssimas às quais chegam são trazidas para a feira. Mas não apenas para alguns ocorrem com frequência, como são bastante prazerosas. "Eu chego a pagar a minha diária para fazer esse tipo de trabalho. Por isso é difícil acontecer de ficar nele como eu até queria. E nunca ia trazer para a feira. Iam pensar que eu estou louco. Ia cobrar quatro mil, cinco mil, por um quadro. Ninguém aqui pagaria" ${ }^{16}$ afirma um artista plástico da Feira da Praia de Iracema. E retoma aquela reflexão sobre a inexistência de olhos apropriados dos frequentadores daquele espaço para reconhecer e ponderar o valor de um trabalho com essas características.

A excepcionalidade dessas peças recai, em primeiro lugar, no quanto mobilizam tempo, atenção e interesse de artistas e artesãos que as confeccionam. ${ }^{17}$ Reside também no próprio material e nos procedimentos de feitura: "São feitas a óleo. Todas as que eu trago são de tinta acrílica. As que eu faço por fora são a óleo, que demora a secar e tudo. Só isso já traz dificuldades. Tem que esperar secar e tudo". Além disso, segundo o que artesãos e artistas plásticos 
da Feira da Praia de Iracema afirmaram, por meio dessas peças querem dizer algo, há alguma mensagem de ordem distinta da que pretendem comunicar por meio dos demais trabalhos que vendem: "Todas as que eu assino têm uma mensagem. Mas nessas eu trago tudo da minha origem. Árvores, os animais de lá, tudo", explica um artista plástico cujos trabalhos na feira habitualmente tematizam itens por completo diferentes. Se todos os trabalhos artísticos e artesanais possuem uma mensagem, esses trabalhos extraordinários possuiriam significado não convencional nem de todo controlado pelo seu produtor, e, por isso, além do espanto que lhes causam, exigiriam outros públicos e espaços de exposição. ${ }^{18}$

\section{VENDA E O LUGAR DO ARTISTA}

Alguns artistas plásticos, como os que expõem em galerias e centros culturais de Fortaleza, e estudiosos, associam com muita frequência a cópia, a repetição, a padronização que reconhecem no artesanato e na arte encontrada em feiras, à venda, vetor que conduziria a confecção de objetos, em processo contrário ao que daria lugar à arte, voltada para a criação. No limite, há identificação dessas ideias com a também amplamente difundida que propõe que o artesanato seria comercial enquanto a arte seria gratuita, submetida inteiramente à fantasia individualizada do artista, ideia à qual costumamos aderir, nas Ciências Sociais, com a facilidade do reconhecimento da sobrevivência como motor importante, e incondicional, da produção artesanal e artística das classes populares. ${ }^{19}$

No Alambrado, um artista plástico pode eventualmente ser assemelhado a artesãos por seus colegas, como a insinuação de que produz "a mesma coisa sempre", porque venderia com facilidade. De fato, na chamada arte, a produção e a venda costumam ser, idealmente, concebidas como operações separadas, e rigidamente hierarquizadas, o artista devendo isentar-se de preocupações comerciais. E parece consistir em regra o artista plástico estar apartado das situações de apresentação de sua obra, ainda aquelas não comerciais, como exposições em museus, centros culturais e galerias, exceto em algumas circunstâncias, como em certas montagens de exposições que exigem decisões atribuídas a ele e nas ocasiões rituais de vernissage. ${ }^{20}$ Tudo indica, de fato, compor a experiência no campo artístico a incorporação da conveniência e legitimidade do afastamento do artista das situações de venda de seu trabalho. Aquela artista plástica da Feira da Praia de Iracema que demonstrava profundo descontentamento com a repetição de seu trabalho para atender ao gosto e à demanda de clientes, assemelhando-a à prostituição, não participava nunca da operação de venda: "Meu marido vem comigo para a feira para isso. Recebe e dá troco para os clientes. Tudo é com ele. Eu não toco em dinheiro".

Nas feiras de artesanato, não raro o artesão está presente vendendo ${ }^{21} \mathrm{e}$, em muitas situações, também trabalhando na confecção de seu produto - bol- 
sas, enfeites de arame, bijuterias, trabalhos em renda e crochê etc. Uma das coordenadoras da Feira da Praia de Iracema explicou que "artesãos não têm estoque; para terem o que vender, têm, muitas vezes, que fazer aqui”, e me conduziu por muitas mesas para vê-los trabalhando - uma senhora confeccionava bolsa com colega ao lado que aprendia, então, determinado acabamento, um senhor fazia enfeites de arame para turistas que diziam as palavras que queriam ver desenhadas na peça, jovem montava um colar etc. Essa junção de esferas para as artes plásticas tão frequentemente separadas é estimulada na feira: "Elas trazem a almofada, tudo. É para o pessoal saber como faz a renda de bilro", a coordenadora agrega a informação àquela sobre a falta de estoque. Agências, como o Ceart, e lojas, hotéis e instituições que viabilizam a produção e a venda do artesanato no Ceará também propõem a presença do artesão trabalhando ao lado das peças que vende. Argumentavam que o "turista gosta", que o "comprador quer ver o artesão trabalhando a peça", certificar-se de que o processo é artesanal - e não industrial -, "autêntico". ${ }^{22}$

Na Feira da Praia de Iracema é muito comum os artistas plásticos também trabalharem na feitura de suas telas enquanto fazem suas vendas. Atribuem a pintura, em geral em tela, já com armação ou não, disposta no chão, nessas condições inadequadas, à falta de tempo para levar em número suficiente trabalhos já finalizados. Nessas situações em que o artista pinta na feira, contudo, exerce uma atração especial, principalmente sobre crianças, para o acompanhamento de seus procedimentos de manipulação do material e de pintura, e para a observação de suas peças já dispostas para a venda. A utilização do espaço de venda para a produção de suas telas contradiz ideia amplamente difundida junto a artistas plásticos, inclusive alguns do Alambrado, e ao senso comum, de que o artista plástico, além de não dever envolver-se com as situações de comercialização de seu trabalho, muito menos deveria produzi-lo durante a venda. O cliente, por seu turno, não teria então acesso nem ao artista, nem a como o trabalho foi produzido. Haveria, em alguma medida, resguardo em relação às circunstâncias de criação, individualizadas, íntimas, libertas de constrangimentos, nas quais, nelas sim, os artistas estariam verdadeiramente implicados.

\section{O SENTIDO DA VENDA E A HIERARQUIA DE TUDO}

A venda, na realidade, tanto para artistas plásticos como para artesãos, é valorizada para além do ganho pecuniário direto que proporciona, isto é, da obtenção de recursos para a sua sobrevivência e para a reposição do material e outros gastos com o trabalho artístico e artesanal. Ela também atesta a aceitação, e por isso o valor, propriamente, da sua produção.

Os diferentes mecanismos de aferição da qualidade artística do trabalho dos artistas plásticos, e dentre eles a venda, estão vinculados às suas distintas 
trajetórias. Para os artistas plásticos da Feira da Praia de Iracema, segundo o que indicaram, a venda constitui o referencial mais importante para a apreciação do valor de seus trabalhos. Já no Alambrado, alguns artistas têm laços mais diretos com o campo artístico, participando de exposições em centros culturais e galerias, no mercado de arte contemporânea, candidatando-se e eventualmente ganhando prêmios, tendo sucesso em seleções que, por exemplo, os levam a ver cópias de seus trabalhos impressas em capas de catálogos telefônicos do estado.

No Ceará, as instâncias de aceitação do artesanato são particularmente numerosas, e dizem respeito, dentre outras, à possibilidade de os artesãos conseguirem "colocar" ou "expor" seus trabalhos em determinadas lojas e feiras, obter financiamento, receber apoio técnico, convites para participar de exposições e feiras organizadas por hotéis, agências do estado ou do governo federal, Sebrae, sindicatos e associações. Artesãos já com reconhecimento público ou mestres da cultura, ${ }^{23}$ ainda quando eventualmente prescindem desses mecanismos de aceitação, ou dispõem de fato de outros, por exemplo, que vinculam sua produção à arte - como estudos acadêmicos, abordagem por mídias, aquisição de peças por colecionadores ou instituições de arte, requisição de trabalhos para exposições -, permanecem considerando a venda, e muito diretamente o preço de venda, indicativo fundamental para a avaliação de sua obra e atestado de seu valor. Para um mestre da cultura, seleiro conhecido internacionalmente, consiste na prova mais importante desse valor, e a que o deixa mais feliz.

O estabelecimento do preço, bem como sua manutenção frente a tentativas de regateá-lo por parte de compradores, compõe o valor também artístico das peças vendidas por artesãos e artistas. Matéria de preocupação da coordenação da Feira de Artesanato da Praia de Iracema, a orientação dada aos artesãos é de manterem o preço de suas peças ainda quando os compradores insistem em baixá-lo: “Turista só quer saber do preço baixo. Eu converso muito com eles [artesãos]. Só quem fez é que sabe quanto vale, o trabalho que deu, o tempo que levou, a importância daquele trabalho". Em que pese a generalizada prática do regateio, e do próprio oferecimento por artesãos de seus trabalhos a preços mais baixos que os inicialmente anunciados - por vezes frente à possibilidade de o comprador levar número maior de peças -, a manutenção dos preços permanece tema bastante tocado por artesãos e artistas plásticos da Feira da Praia de Iracema quando tratam do valor artístico do que produzem.

Não baixar o preço estipulado para suas peças aparece de fato como operação associada pelos artistas e artesãos ao valor que atribuem a elas. Aqueles trabalhos excepcionais de artistas plásticos da Feira da Praia de Iracema só poderiam ser vendidos a preço completamente impraticável, e para muito além do tanto de tempo e de material gastos na sua feitura. No Alambrado, muitos artistas, ao demarcarem a diferença de sua situação frente à de artesãos e de artistas que vendem seus trabalhos em feiras de artesanato, afirmaram jamais 
negociar o valor do que vendem: "Prefiro não vender. Mas o que eu peço, acabam dando. Não demora tanto e compram".

O interesse, e assim a aquisição de seus trabalhos pelo preço que estipulam, é vinculado por artesãos e artistas plásticos não apenas ao poder aquisitivo, mas especialmente à capacidade de os indivíduos avaliarem adequadamente o que veem. Essa associação teria a ver com o tipo de público que frequenta as feiras e também a orla da Beira Mar, bastante diversificado e, segundo eles, poucas vezes qualificado, ou "culto", para quem nem sempre o valor propriamente artístico dos trabalhos é devidamente aquilatado. "Eu não pinto para gringo peão", dizia um artista plástico do Alambrado. "Meus quadros exigem conhecer arte, ter um mínimo de critério", completava. Segundo artistas que vendem nesse espaço, a imensa maioria de turistas estrangeiros que visita Fortaleza e se interessa pelos quadros que expõem é formada por "braçais", que preferem justamente trabalhos que representam jangadas, coqueiros ou "um Lampião": "Aí o camarada vai botar na parede da sala dele e dizer: 'Estive lá'”.

O fato de "exporem" em feiras de artesanato é apresentado como incômodo para os artistas plásticos que não consideram ser esse um lugar apropriado para a venda de objetos de arte, e, para alguns, mesmo da "arte comercial", porque voltado para público altamente diversificado e bastante desqualificado, "praticamente rua": "Quando meu empresário me pediu para vender na rua, começou a não dar certo. Vendia muito, mais que nas galerias, mas desvalorizou. Galeria é galeria. Rua é rua. Desvaloriza. Daí eu voltei para o Brasil", dizia a artista plástica profundamente insatisfeita por vender seu trabalho em feira de artesanato, explicando por que sua carreira não tinha dado certo depois de período de sucesso em país europeu. Na realidade, a galeria costuma ser aventada por muitos desses artistas plásticos como local ideal, se não para a venda de toda a arte que produzem, ao menos daquela arte que resulta de processos criativos especiais, como os que tratamos anteriormente.

Para alguns artistas plásticos, como vimos, seu envolvimento direto na venda do trabalho parece já indicar tensa necessidade de abrir mão daquele lugar do artista voltado exclusivamente para a criação. Ao lado disso, os espaços para a venda são valorizados ou desvalorizados por eles por meio de diferentes critérios. Algumas avaliações dos espaços dizem respeito às condições de exposição para os passantes, o conforto para os que permanecem horas seguidas vendendo seus produtos, a organização da infraestrutura da feira e higiene, propaganda, visibilidade e acesso para, especialmente, turistas. ${ }^{24}$ Preferem, por isso, uma feira a outra, gostariam de estar nesta ou naquela. A Feira da Praia de Iracema é avaliada como pouco frequentada, mas mais organizada e "exclusiva" - isto é, sem a presença de ambulantes - que os espaços onde vendiam seus trabalhos na região da Beira Mar.

Suas oficinas, ou seus espaços, ${ }^{25}$ locais onde produzem boa parte de seus trabalhos, são muitas vezes mencionados como lugares algo superiores à feira 
de artesanato, e onde eventualmente seus trabalhos mais interessantes seriam procurados. Artistas plásticos da Feira da Praia de Iracema com frequência referem-se a galerias como os espaços nos quais poderiam encontrar pessoas dispostas a compreender o significado e capazes de aferir o valor do seu trabalho. Origem social, poder aquisitivo e o local de frequentação são associados por esses artistas ao possível interesse e eventual aquisição de seus trabalhos mais especiais, em geral por pessoas das classes abastadas: “Tem pessoas que sabem até se aproximar de uma obra de arte, sabem como chegar nela. Devagar. Em silêncio. Calmos. Os caras aprenderam a procurar, aprenderam a ver. Aqui na feira, tem vezes que nem se interessam por quem fez". Sobre o acesso às galerias, afirmam nunca terem tido, alguns esperando vivamente a "sorte" de vir a expor seus trabalhos nelas.

Sua origem social, e respectiva necessidade de trabalhar para a sobrevivência, é acionada como fator que os levaria a não ter contato com as galerias: “Não, não conheço o pessoal de galeria. E eu gostaria de fazer uma peça, uma assim totalmente nova, passar outro tempo e fazer outra peça, só fazer essas peças com a minha história. Mas tenho que vender meus trabalhos aqui na feira, a bem dizer, um local humilde. Nesse ponto, é aquilo: nesse ponto eu não sou um artista, nesse ponto eu sou mais um trabalhador. E eu sou um artista".

A hierarquia dos lugares de exposição é, assim, correlacionada a diferenciações importantes dos expositores, de quem observa e compra, e do próprio valor do que é exposto. A esse respeito, fatos ocorridos durante entrevista para esta pesquisa foram apontados por artista plástico da Feira da Praia de Iracema como comprovação da distância entre o que vive e a situação ideal que presume encontrar em galerias: uma criança comendo pipoca passava o dedo em uma de suas telas enquanto os pais, distraídos, comentavam um outro trabalho exposto; turista agachava-se ao lado de uma enorme tela retratando índia, posava, e seu companheiro fazia foto, sem pedir licença ao artista.

\section{VENDA NOS OLHOS?}

Para quem artistas e artesãos que trabalham na Feira da Praia de Iracema produzem consiste em vetor que perpassa não apenas o processo criativo por meio do qual por vezes desatam percursos bastante definidos de elaboração de seus trabalhos. Esse pouso, o da venda, está amarrado a lugares para os quais afluem, ou poderiam afluir, reais ou potenciais compradores, isto é, admiradores de sua arte. Que estes indivíduos interessados existem, embora possam circular por espaços desconhecidos, ou aos quais artesãos e alguns artistas não têm acesso, como galerias, é fato que sustenta boa parte das iniciativas que resultam em uma produção que, como vimos, seus criadores avaliam como completamente inadequada frente à sua rotina de trabalho e ao local onde, e para quem, efetivamente vendem suas peças. 
Desintegrada como última operação da arte para muitos que se debruçam sobre a arte contemporânea, ou a arte acessada por especialistas e classes abastadas, a venda opera como dimensão constitutiva da arte produzida por artesãos e artistas plásticos que trabalham em feiras de artesanato. Para muito além da necessária e inexorável repercussão que tem para a sua sobrevivência, e para a própria continuidade de sua produção, é por meio da venda que o valor de seu trabalho pode ser aventado, e com ele a própria oportunidade da comunicação que desejam e presumem instituir no repasse das peças que criam. Se há, ali, e naquele momento, olhos que possam verdadeiramente reconhecer e assim compor o valor do que produzem, isso irá muitas vezes determinar o que fazem e se continuarão a fazê-lo. O fato de essa visão que tanto almejam ser para eles, de alguma maneira, atributo de indivíduos normalmente oriundos de classes privilegiadas, que circulam por lugares nem sempre acessíveis a seus trabalhos, e a eles mesmos, consiste em problema que muitos indicam ainda não saber como resolver.

Parece haver algo inconveniente em imprimir ênfase no aspecto comercial da arte quando nos detemos também em elementos propriamente criativos e nos sentidos atribuídos pelos artistas à sua produção. Com efeito, não é de todo incomum estudar o artesanato e a arte produzida por artistas das classes populares sem que consideremos a venda como momento, operação, dimensão crucial. Ao nos abstrairmos dessa dimensão, analisamos a arte de artesãos e artistas plásticos que vendem seus trabalhos na rua a partir do ponto de vista do artista despreocupado quanto aos aspectos vinculados ao comércio de suas criações. De fato, não raro nos estudos sobre os artesãos e sobre os artistas que trabalham em feiras de artesanato, a venda ou é esquecida ou é desvalorizada como espécie de invasão interesseira que diminuiria o valor verdadeiramente artístico do seu trabalho. Ao contrário do que vimos, em análises desse tipo essa arte poderia então existir independente da sobrevivência de seus produtores e do seu desejo de controlar e expandir o alcance do que querem, com ela, comunicar. 
Lígia Dabul é doutora em Sociologia, com pós-doutorado em Antropologia Social na School of Social Sciences da University of Manchester. Professora Associada do Departamento de Sociologia da Universidade Federal Fluminense (UFF), coordena o Nectar Núcleo de Estudos Cidadania, Trabalho e Arte, e está vinculada aos

Programas de Pós-Graduação em Sociologia e em Estudos Contemporâneos das Artes da UFF. É pesquisadora do Conselho Nacional de Desenvolvimento Científico e Tecnológico (CNPq), tem pesquisas sobre públicos das artes, processos criativos, configurações de práticas e identidades de artista. É autora de “Sociabilité et les sens de l'art" (2014) e, com Rodrigo Barreto, “Fim de linha na arte: pintores retratistas de rua" (2014, no prelo). 


\section{NOTAS}

* A pesquisa que deu origem a este artigo contou com o apoio do CNPq - Conselho Nacional de Desenvolvimento Científico e Tecnológico e da Faperj - Fundação Carlos Chagas Filho de Amparo à Pesquisa do Estado do Rio de Janeiro. Agradeço a Peregrina Capelo, a Maria Sylvia Porto Alegre, a Dodora Guimarães e a Ismael Pordeus Jr. pelas indicações preciosas para essa pesquisa, naturalmente eu me responsabilizando por seus resultados. Seguindo acerto feito com artesãos e artistas plásticos entrevistados, evitaremos aqui, em muitos momentos, apresentar dados que permitam sua identificação.

I Um turista receberá sugestões, já em mapas distribuídos no Aeroporto Internacional Pinto Martins pela Secretaria de Turismo do Governo do Estado do Ceará, e também no hotel e de moradores da cidade, para conhecer a "Feirinha da Beira Mar", ou "Feira de Artesanato da Beira Mar", ou ainda "Polo Artesanal da Beira Mar", dentre outras designações: "Quem vem a Fortaleza não pode deixar de conhecer esse cartão-postal", lemos em um mapa, referindo-se a toda área da Avenida Beira Mar. Ver Mapa No Ceará, você já tem uma companhia para onde for: a alegria, Secretaria de Turismo do Ceará, s/d.

2 São divergentes as informações a respeito do número e da organização dessas pequenas feiras. Membros de associação de artesãos, do sindicato e outros artesãos entrevistados informaram ora que se tratava de apenas uma associação, ora que eram diversas, ou ainda que somente o sindicato organizava as feiras de artesanato da orla antes da operação de regularização do comércio dessa área da cidade.

3 Dentre os diversos acontecimentos que levaram à nova organização do comércio da área, foram noticiados amplamente a greve de fome de vendedora ambulante, que permaneceu deitada dentro de caixão por dias, e o protesto do presidente da Associação dos Feirantes da Grande Fortaleza. Amarrado a uma cruz, manteve-se durante alguns dias na calçada da avenida Beira Mar manifestando-se contra o impedimento dos comerciantes associados ao seu sindicato e não cadastrados pela Prefeitura de venderem mercadorias na área, e contra o tratamento "privilegiado" concedido aos artesãos, remetidos para a então em formação Feira de Artesanato da Praia de Iracema. 
4 Amplamente utilizado por artesãos, pesquisadores, comerciantes, agências e diversos atores sociais envolvidos no estudo, produção e distribuição do artesanato do Ceará, o termo tipologia corresponde, nas situações tratadas neste estudo, mais a tipo de artesanato que ao sistema usado para classificá-lo. Consistem, então, cada uma das tipologias, em categorias que abrangem e diferenciam peças artesanais, embora variando consideravelmente de conteúdo de acordo com o contexto de sua utilização. As tipologias podem estar remetidas de diferentes maneiras, por exemplo, a matérias-primas, técnicas, tradições, regiões, medidas e valores, e agregadas ao importante sistema de disciplinamento, produção e circulação do artesanato cearense.

5 Artesãos entrevistados fazem críticas a respeito do acesso diferenciado que o Siara e associações de artesãos propiciam para este ou aquele grupo de associados, alguns não sendo informados de diversas oportunidades, por exemplo, de participação em cursos e feiras.

6 O número e a composição das alas variaram desde a criação da feira, quando havia nove delas. Também a forma de designá-las tem variado com o tempo. Mesmo hoje, entre participantes, coordenadores e curadores (ver nota 8), há inúmeras maneiras de nomeá-las. "Ala dos quadros", "ala das telas", "ala dos artistas", foram designações da "ala dos artistas plásticos", forma que, na imprensa, aparecia com mais frequência quando da criação da feira e que ainda hoje é muito utilizada.

7 Há versões de artistas plásticos diversos, e de artesãos que participam desde o início da feira, que afirmam terem sido cerca de 100 os artistas plásticos que acorreram para lá.

8 A organização da feira inclui coordenadores, incumbidos da administração e da relação da feira com o sindicato, e os curadores das alas, que controlam a qualidade e a adequação das peças levadas para a venda por artesãos aos critérios estabelecidos pelo sindicato para que sejam admitidas na feira. Durante a pesquisa, tivemos notícias de negociações de artesãos, curadores e sindicato em relação à mudança de algumas características das peças, como elementos de brilho em bijuterias, que fugiriam ao padrão regional, ou rústico, mas que facilitariam muito a aceitação do público e, então, a venda. "As artesãs que trabalham com bi- 
juteria estavam no ponto de desistir de vir. Agora vendem muito mais", esclarecia uma coordenadora.

9 Segundo artistas e artesãos entrevistados, o desejo de sair da feira não tem a ver com a relação que mantêm com os demais artistas e artesãos que lá também "expõem" seu trabalho, de colaboração e amizade, construída em mais de dois anos de convívio. De fato, presenciei diversas demonstrações de confiança e proximidade, por exemplo artistas plásticos utilizando em suas vendas máquina para cartão de crédito de artesão, participando de conversas e comemorações, na feira, de aniversário de artesãos, e dividindo a merenda com eles.

Io A extensão dessa diferenciação é de fato larga, incluindo ambientes da chamada arte contemporânea. Em curso de pintura contemporânea em grande escola de artes visuais do Rio de Janeiro, o professor, um artista plástico, reconhecia ênfase no tratamento de materiais pelos alunos com prática em artesanato, e a relacionava "a uma mecânica manual, à automatização de procedimentos que reproduzem um padrão decorativo, sem que o aluno se preocupe em criar uma linguagem com a pintura" (Dabul, 200I: I 25).

I I H. Becker atém-se a duas possibilidades: "In the first case, participants in an art world borrow from or take over a craft world; in the second, a mature art world begins to exhibit some of the characteristic features of craft worlds" (I982: 272).

I 2 Manoel de Barros (I997: I I), poeta, define esse processo: "Repetir repetir - até ficar diferente./Repetir é um dom do estilo."

I3 Artistas plásticos da Feira da Praia de Iracema apresentaram avaliações muito distintas dos artistas do Alambrado. Alguns os reverenciam, "os pioneiros", cuja permanência segura de seu ponto de exposição e venda admiram como forma de resistência àquela ação da Prefeitura que atingiu tantos artistas. Outros os veem como "de salto alto", dispostos a "mostrar além do que têm", achando-se superiores a todos os outros artistas que trabalham na orla da cidade.

I4 Não consistindo em nosso objeto, podemos, contudo, remarcar o caráter generativo que a improvisação assume na arte, determinando efetivamente possibilidades criativas que se estabelecem e se fixam por algum tempo, e assim 
feições mais permanentes dos seus resultados. A esse respeito, ver Robert Faulkner (2006). Noutra modalidade de pesquisa, focada mais diretamente no "work itself" (Becker, 2006), talvez partíssemos justamente da relevância desses processos de adaptação a demandas de clientes e às do material para a constituição da arte.

I5 Também não podemos nos deter nas operações de manipulação e apresentação, pelos artesãos, de repertório avaliado amplamente - por agências que estimulam a produção e venda de artesanato, como Sebrae e Ceart, de instituições como o sindicato e associações, e atores sociais como estudiosos, compradores e vendedores do artesanato cearense - como regional, autêntico, rústico, artístico, cearense em suas peças. Diversos pesquisadores, como Machiko Kusahara (I997), indicam experiências dessa natureza como elas próprias, contra o que normalmente concebemos como valor artístico, a originalidade, definidoras dos atributos criativos e notáveis de muitos produtos artísticos.

I6 Mas artistas plásticos também relataram situações de venda, noutros lugares, de trabalhos frutos de devaneio e intensa pesquisa. Esse mesmo artista plástico conta que um rico fazendeiro, por "outros caminhos", adquiriu por milhares de reais peça que demorou muitíssimo a confeccionar e que nunca expôs, nem exporia, na feira.

I7 E estamos aqui nos referindo a processo criativo que inclui experiências para além do insight, aproximando-se consideravelmente às do devaneio, ou entusiasmo. A respeito dessa distinção, ver Fernando Muniz (20I I).

I8 Não pudemos avaliar nessa pesquisa as implicações de artesãos e artistas plásticos que trabalham em feiras utilizarem o termo "expor" para referirem-se a "vender" ou "colocar" ou "dispor" suas peças em algum espaço para comercializá-las.

I9 Ver em H. Becker (I982) o quanto a submissão ao agrado de um contratante ou cliente compõe a categoria artesanato e moveria trânsitos da arte em sua direção. Ver em Pierre Bourdieu (2007) a proposição do quanto o gosto das classes populares estaria identificado a uma estética da necessidade, enquanto o das classes abastadas estaria justamente correlacionado a uma noção de liberdade em relação às demandas da sobrevivência. 
20 Ver considerações a respeito de mudanças na chamada arte contemporânea em relação ao contato do artista com seu público em Dabul (20I I)

2 I Na Feira de Artesanato da Praia de Iracema, trata-se de exigência da coordenação que a venda seja feita pelo próprio artesão ou artista plástico.

22 Diversos são os registros e análises das determinações e implicações dessa simultaneidade de venda e produção de artesanato. Ver, por exemplo, em Antonio M. C. Novaes (20I I), descrição da atuação de artesãos de Juazeiro do Norte, Ceará.

23 Trata-se de distinção atribuída, desde 2004, pelo Governo do Estado do Ceará por meio de sua Secretaria de Cultura, a indivíduos e, a partir de 2006, também a grupos e coletividades cuja prática corresponderia a uma tradição cultural que mereceria ser valorizada e preservada.

24 Artesãos e artistas plásticos da Feira da Praia de Iracema indicam recente e importante mudança na sua clientela, dada a diminuição do número de turistas europeus e aumento dos brasileiros e, mais que isso, a cada vez mais frequente compra de telas e outras peças por moradores de bairros populares próximos.

25 A maioria dos artistas plásticos da Feira da Praia de Iracema refere-se a seu espaço de trabalho fora da feira como oficina, tal como os artesãos, ou espaço. Muitos avisam que não têm ou não se referem a ele como ateliê, como fazem muitos artistas plásticos, como alguns do Alambrado. Indicam também, com frequência, que sua oficina funciona na sua casa.

\section{REFERÊNCIAS BIBLIOGRÁFICAS}

Carvalho, Gilmar de; Guimarães, Dodora \& Barreira, Gentil. (2000). Ceará feito à mão. Fortaleza: Terra da Luz Editorial.

Barros, Manoel. (I997). O livro das ignorãças. Rio de Janeiro: Record.

Becker, Howard. (2006). The work itself. In: Becker, Howard S., Faulkner, Robert \& Kirshenblatt-Glimblett, Barbara (orgs.). Art from start to finish. Jazz, painting, writing, and other improvisations. Chicago/Londres: The University of Chicago Press, p. 2I-30. 
Becker, Howard. (1982). Art worlds. Berkeley/Los Angeles/ Londres: University of California Press.

Bourdieu, Pierre. (2007). A distinção: crítica social do julgamento. São Paulo/Porto Alegre: Edusp/Zouk.

Dabul, Lígia. (20 I I). Rápidas passagens e afinidades com a arte contemporânea. O Público e o Privado, I7, p. 87-95.

Dabul, Lígia. (200I). Um percurso da pintura. A produção de identidades de artista. Niterói: Eduff.

Elias, Norbert. (I995). Mozart. Sociologia de um gênio. Rio de Janeiro: Zahar.

Faulkner, Robert. (2006). Shedding culture. In: Becker, Howard S., Faulkner, Robert \& Kirshenblatt-Glimblett, Barbara (orgs.). Art from start to finish. Jazz, painting, writing, and other improvisations. Chicago/Londres: The University of Chicago Press, p. 9 I-I I 7.

Hallam, Elizabeth \& Ingold, Tim (orgs.). (2007). Creativity and cultural improvisation: An introduction. In: Creativity and cultural improvisation. Oxford/Nova York: Berg, p. I-24.

Heinich, Nathalie. (1996). Être artiste. Les transformations du statut des peintres et des sculpteurs. Paris: Klincksieck.

Kusahara, Machiko. (I997). Sobre a originalidade e a cultura japonesa. In: Domingues, Diana (org.). A arte no século XXI: A humanização das tecnologias. São Paulo: Ed. Unesp, p. 247-256.

Muniz, Fernando. (20II). Apresentação. As teorias do entusiasmo. In: Muniz, Fernando (org.). As artes do entusiasmo: a inspiração da Grécia Antiga à contemporaneidade. Rio de Janeiro: 7Letras, p. I3-I8.

Novaes, Antonio Marcelo Cavalcanti. (20 I I). O processo de artificação em Juazeiro do Norte. Análise do Centro Cultural Mestre Noza. Tese de doutorado. Universidade Federal do Ceará.

Porto Alegre, Maria Sylvia. (1994). Mãos de mestre: itinerários da arte e da tradição. São Paulo: Maltese.

Silva, Emanuelle K. R. da. (20 I I). Quando a cultura entra na moda: Mercantilização do artesanato e suas repercussões no cotidiano de bordadeiras de Maranguape. Fortaleza: Ed. UFC. 
Palavras-chave

Arte; Este artigo trata de aspecto nem sempre enfocado da arte Artista plástico;

Venda;

Feira de artesanato;

Criação.

Keywords

Art; This paper discusses an aspect that is not always regarded

Plastic artist;

Sale;

Handicrafts market;

Creation. a venda, refletindo sobre as formas por meio das quais ela se liga a procedimentos criativos e a diversos atributos que costumam compor a identidade de artista, como o caráter original, individualizado e comercialmente desinteressado de sua produção. Analisando situação na qual artistas plásticos trabalham em feira de artesanato de Fortaleza, Estado do Ceará - Brasil, as aproximações e os distanciamentos das categorias artista/arte, de um lado, das categorias artesão/artesanato, de outro, contribuem para a reflexão sobre o significado variável de procedimentos vinculados à venda de seus produtos, as condições nas quais se realiza, e o quanto concorre para a diferenciação dos e entre artistas plásticos.

\section{PLASTIC ARTS AT A HANDICRAFTS MARKET:}

SELLING, CREATING AND HAVING PROPER EYES TO SEE ART

\section{Abstract} in art - the sale -, pondering on the ways whereby it is linked to creation processes and to several atributes that usually add to artists' identity, such as originality, which is individualised and not interested in commercialising
ARTES PLÁSTICAS EM FEIRA

DE ARTESANATO: VENDA, CRIAÇÃO E OS OLHOS PARA VER A ARTE

\section{Resumo} with products. By analysing a situation in which plastic artists work at a handicrafts market in Fortaleza, state of Ceará - Brazil, we discover that the similarities and differences between, on the one hand, the artist/art categories and the craftworker/handicraft ones, on the other, play a role when pondering on the variable meaning of procedures associated to selling products, the conditions in which it is done and how much it leads to distinguishing plastic artists, not only from other artists but also among them. 